\title{
Volatile anaesthetics for analgesia and sedation in patients after abdominal surgery in ICU
}

\author{
VI Potievskaya*, IV Molchanov, TV Krivenko \\ From ESICM LIVES 2015 \\ Berlin, Germany. 3-7 October 2015
}

\section{Introduction}

It is known that volatile agents are efficient and safe in general anaesthesia and may be used in ICU as alternative to intravenous medications [1]. Neverhteless we lack information about special features of analgesia and sedation and haemodynamic changes during action of inhalational anaesthetics in patients after surgery.

\section{Objectives}

The objective of this prospective study was to evaluate efficacy of analgesia and sedation with volatile anaesthetic sevoflurane and its influence on haemodynamics in mechanically ventilated patients in ICU.

\section{Methods}

37 patients on prolonged mechanical ventilation (20 males, 17 females) after abdominal surgery were followed up in ICU. The sedation level was evaluated with RASS scale and auditory evoked potentials (AEP), analgesia - with the analgesia/nociceptive index (ANI), based on spectral analysis of RR intervals [2], hemodynamic parameters - by impedance plethysmography. Sedation was performed by AnaConDa (anaesthetic conserving device) with sevoflurane. Mean duration of sedation was 5 hours. Statistical analysis was performed by
Wilcoxon matching pairs test. Data are presented as mean and standard deviation.

\section{Results}

The mean rate of sevoflurane infusion was $3.0 \pm 0.6 \mathrm{ml} / \mathrm{h}$, sevoflurane concentration $-0.5 \pm 0.2 \%$. We achieved the target sedation level (from -2 to -3 RASS) in all the patients. Significant fall of AAI index (AEP) was observed during the period of sedation (from 67.40 (12.5) to 42.4 $(9.3)(\mathrm{p}<0.05)$. ANI rised during the period of sedation from 74.8 (6.8) to 96.0 (2.34), $\mathrm{p}<0.05$, and reflected adequate analgesia. MAP decreased during the therapy but remained in normal ranges. Increase of cardiac index (CI) and fall of system vascular resistance (SVR) (table) reflected more effective heart work that may be induced by cardioprotective effect of sevoflurane.

\section{Conclusions}

Inhalational anaesthetic sevoflurane provides adequate level of sedation and analgesia during first 5 hours in patients in ICU after surgery and has no negative influence on circulation parameters.

Published: 1 October 2015

Table 1 Influence of Sevoflurane on Haemodynamics

\begin{tabular}{lllllll}
\hline Parameters & Baseline & 1 hour & 2 hour & 3 hour & 4 hour & $\mathbf{5}$ hour \\
\hline $\mathrm{MAP}, \mathrm{mm} \mathrm{Hg}$ & $90.4(12,5)$ & $89.0(12,0)$ & $85,9(10.8)^{*}$ & $82.7(7.5)^{*}$ & $81.6(8.8)^{*}$ & $80.5(10.9)^{*}$ \\
\hline $\mathrm{Cl}, \mathrm{ml} / \mathrm{min} / \mathrm{m} 2$ & $1.64(0.71)$ & $1.85(0.74)$ & $2.10(0.68)^{*}$ & $2.20(0,65)^{*}$ & $2.13(0,11)^{*}$ & $2.23(0.30)^{*}$ \\
\hline $\mathrm{SVR}$, din.c.cm-5 & $3116.00(950.15)$ & $3097.75(923.07)$ & $3142.25(940.86)$ & $2920,75(986.36)$ & $2100,3^{*}(130.42)$ & $2387,6^{*}(584.0)$ \\
\hline
\end{tabular}

* - significant comparing with baseline $(p<0,05)$. 


\section{References}

1. Soro Marina, Gallego Lucía, Silva Vanessa, et al: Cardioprotective effect of sevoflurane and propofol during anaesthesia and the postoperative period in coronary bypass graft surgery: a double-blind randomised study. Eur J Anaesthesiol 2012, 29(12):561-9, Dec 2.

2. Chumachenko ED: Analgesia nociception index: from objective evaluation of nociception to analgesia improvement. Clinical Anesthesiology \& Intensive Care, N 2014, 2(4):90-102.

doi:10.1186/2197-425X-3-S1-A329

Cite this article as: Potievskaya et al: Volatile anaesthetics for analgesia and sedation in patients after abdominal surgery in ICU. Intensive Care Medicine Experimental 2015 3(Suppl 1):A329.

\section{Submit your manuscript to a SpringerOpen ${ }^{\mathcal{O}}$ journal and benefit from:}

- Convenient online submission

- Rigorous peer review

- Immediate publication on acceptance

- Open access: articles freely available online

- High visibility within the field

- Retaining the copyright to your article

Submit your next manuscript at $\gg$ springeropen.com 